\title{
THE GENUS CORISPERMUM L. (AMARANTHACEAE) IN THE BALTIC STATES
}

\author{
Pēteris Evarts-Bunders ${ }^{1 *}$, Gunta Evarte-Bundere ${ }^{1}$, Maija Medne ${ }^{1}$, Aiva Bojāêe ${ }^{1,2}$, \\ Dana KrasnopolsKa ${ }^{1}$, Inita SVILĀNE ${ }^{1}$
}

${ }^{1}$ Daugavpils University, Institute of Life Sciences and Technology, Parādes Str. 1A, 5401 Daugavpils, Latvia

${ }^{2}$ National Botanical Garden, Dendroflora Department, Miera Str. 1, 2169 Salaspils, Latvia

*Corresponding author. E-mail: peteris.evarts@biology.lv

\begin{abstract}
Evarts-Bunders P., Evarte-Bundere G., Medne M., Bojāre A., Krasnopoḷska D., Svilāne I., 2020: The genus Corispermum L. (Amaranthaceae) in the Baltic States. - Botanica, 26(1): 61-75.

The paper presents the data on taxonomical diversity and distribution patterns and dynamics of the Corispermum species in the Baltic States over the last hundred years. Field studies and the herbarium material analyses were carried out. The distribution dynamics was analysed by comparing all known localities of the Corispermum species in two time periods: by 1990, and from 1991 to the present. Analysis of the herbarium material confirmed that currently there are four species in the Baltic States: Corispermum hyssopifolium, C. declinatum, C. intermedium and C. pallasii. The only endemic species to the Eastern Baltic Region, C. intermedium, is considered as typical for annual vegetation on embryonic shifting dunes and other coastal habitats. In Lithuania, this species is considered extinct or almost extinct, as has not been found for more than 30 years, only its hybrids with C. pallasii. The largest and most stable population of $C$. intermedium has been found on the eastern shore of the Gulf of Rīga in Latvia. Other species such as ephemerophytic C. hyssopifolium and C. declinatum also prefer dry and disturbed habitats. Both have become less frequent in recent years. However, potentially invasive $C$. pallasii has been observed in the region with increasing distribution dynamics. The Estonian and Latvian herbaria analysis confirmed that all specimens previously identified as C. algidum after re-examination were identified as C. pallasii or C. intermedium and more often as hybrid C. intermedium $\times$ C. pallasii.
\end{abstract}

Keywords: alien species, Baltic States, chorology, coastal habitats, Corispermum, distribution dynamics.

\section{INTRODUCTION}

Corispermum L. is a genus of annual hermaphroditic herbaceous plants of the Northern Hemisphere considered to be among the most taxonomically complicated genera of Amaranthaceae. Species-level identification is also very complicated because of the morphological similarity of species, hybridisation as well as phenotypic plasticity and different habitus at different stages of development (SuKHORUKOv, 2007, 2014). The number of species and morphological boundaries between them are understood differently by various botanists in the Baltic States. Species identification in the genus is primarily based on fruit characters and presence or absence of perianth segments.

The genus probably originated in arid regions of Eurasia. It is estimated that it includes about 68 species occurring in the Holarctic region. Nowadays, species of the Corispermum are native and sometimes widespread in Asia, Europe, and North America (Mosyakin, 2003). The Corispermum species are annuals, and most of these are psammophytes (GALENIEKS, 1955; Priedītis, 2014).

The genus Corispermum is considered as phylogenetically relatively young, as evidenced by morphological similarity of species, karyotypic similarity $(2 n=18)$ as well as the distinct occurrence of 
species in synanthropic habitats and relatively extensive hybridisation. In contrast, in natural habitats, it is not a case due to geographic, ecological and other isolation mechanisms (STRAZDiN̦š, 1985).

Taxonomic situation regarding the Corispermum species abundance and distribution in the territory of the Baltic States is quite complex and changing. According to the old literature, for a decade since the first publication of the Corispermum corresponding to the territory of Latvia, only three species had been reported: C. intermedium Schweigg., C. hyssopifolium L. (Fleischer, 1839; Klinge, 1882; Bitckis, 1923) and C. orientale Lam. (STARCS, 1936). The first comprehensive review of the Corispermum genus in the Baltic States was carried out by J. Strazdiņš (1985), who published an extensive study on it. It is considered to be the most significant comprehensive genus analysis in the Baltic States. The author based the approach of species identification on the research of two botanists ILJiN (1929) and KLOKOv (1960). According to the latest official list of vascular plants in Latvia, the genus is represented by six species: C. algidum Iljin, C. declinatum Steph. ex Iljin, C. hyssopifolium, C. intermedium, C. leptopterum (Aschers.) Iljin and C. orientale (StrazdiNš̌, 1993; Gavrilova \& Šulcs, 1999). There are several hybrids mentioned in the flora of Latvia and the Baltic States with different level of occurrence, vitality and fertility: $C$. algidum $\times$ C. declinatum, C. algidum $\times$ C. leptopterum, $C$. declinatum $\times$ C. leptopterum $(C . \times$ latvicum $), C$. hyssopifolium $\times$ C. intermedium, C. hyssopifolium $\times$ C. leptopterum and C. intermedium $\times$ C. leptopterum (StRAZDiN̦š, 1985, 1993).

The number of the Corispermum species differs within the Baltic States. Until 1971, only one alien species was referred to the territory of Estonia; it was reported as C. sibiricum Iljin (EICHWALd et al., 1971). Later four species were reported new to Estonia: C. algidum, C. declinatum, C. hyssopifolium and C. leptopterum (LeHt et al., 2007). Recent studies have also discovered the fifth species - native C. intermedium present in Estonia (EvARTs-Bunders et al., 2016). Four species are listed in the latest official list of vascular plants of Lithuania $-C$. declinatum, C. intermedium, $C$. hyssopifolium and C. hybridum Besser ex Andrz. There are also two species indicated as possibly present in the territory of Lithuania: C. sibiricum and C. marschallii Steven (GuDžInSKAS, 1999, 2000; GudžInsKas \& SukHorukov, 2004).
In the Scandinavian region, only one species has been mentioned - C. pallasii Steven (KuRTTO, 2001; Mossberg \& Stenberg, 2010). The same is in the Republic of Belarus - in the previous literature, only C. marschallii had been listed as present in the country (ILJIN, 1949). M.V. Klokov had described several new species: $C$. astrachanicum Klok., C. calvum Klok., C. nitidulum Klok., C. stenopterum Klok., C. volgicum Klok. (KLoKov, 1960) and C. bjelorussicum Klok. et Krasnova (KLoKov et al., 1981), which in later works was recognized as synonyms of C. marschallii, C. nitidum Kit. et Schult. and C. pallasii (Tzvelev, 2012). In more recent works, other three species have been mentioned $-C$. pallasii (Dubovik et al., 2011), C. declinatum and C. nitidum (DuboviK et al., 2014). The official list of vascular plants of Poland includes five species of the Corispemum genus: C. nitidum, C. hyssopifolium, C. intermedium, C. leptopterum and C. marschallii (MireK et al., 2002). The closer to the biodiversity centre of the Corispermum genus, the more species appear to be present: 13 species have been recorded new to the north-west region of Russia (all of these including species mentioned in the Baltic States) (Mosyakin, 1996).

Particular attention should be paid to $C$. intermedium, which is considered to be rare, native endemic species, occurring only on the seashore of Latvia and Lithuania (STRAZDIN̦Š, 1993). Distribution of this species is highly questionable due to the latest studies on the southern coast of the Baltic Sea (DoLNIK et al., 2011) and in the coastal territories of Latvia and Estonia (EvARTs-Bunders et al., 2016). They are indicating possible extinction of $C$. intermedium and replacement by neophyte $C$. pallasii (syn. C. leptopterum). Both of these species are often confused due to their similar morphological characters, historically incorrectly described in Flora Europaea (AELlen \& AKEROYD, 1993), leading to further misidentification in several countries.

The preliminary study on herbaria specimens from the Baltic States showed many cases of misidentifications within species of the genus Corispermum. The latest studies of the genus distribution in the Baltic Region led to the necessity for updating and clarification of species composition of the genus Corispermum and their distribution patterns in the Baltic States.

The study aimed to evaluate all available data of 
the Corispermum spp. in the Baltic States, clarify the distribution dynamics during the last century, compare the main morphological differences and explain the floristic status of all Corispermum taxa.

\section{MATERIALS AND METHODS}

Comprehensive revision of the localities of the Corispermum species as well as revision of all major herbaria was carried out from 2008 to 2019: in Latvia - Daugavpils University, Institute of Life Sciences and Technology, Laboratory of Botany (DAU, 199 herbarium specimens, largest part collected during this study), the University of Latvia, Institute of Biology, Laboratory of Botany (LATV, 324 herbaria specimens), the University of Latvia, Museum of Botany (RIG, 47 herbaria specimens), Estonia - the Estonian University of Life Sciences, Institute of Agricultural and Environmental Sciences, Department of Botany (TAA, 23 herbaria specimens), the University of Tartu Natural History Museum (TU, 40 herbaria specimens), Lithuania - the Nature Research Centre, Institute of Botany (BILAS, 137 herbaria specimens), Vilnius University (WI, 41 herbaria specimens). There was also the work done with two main herbaria of the Republic of Belarus - the National Academy of Sciences of Belarus, Institute of Experimental Botany (MSK) and Belarusian State University, Department of Botany (MSKU). Some critical taxa (C. marschallii, C. algidum, C. sibiricum, $C$. nitidum) were studied in the Herbarium of the Russian Academy of Sciences, Komarov Botanical Institute (LE) and the Herbarium of Altai State University (ALTB).

Field studies were carried out during five years from 2015 until 2019. The flora of annual vegetation on the seashore, embryonic dunes with active migrating sand and disturbed grey dunes and wooded dunes were studied during the seasons of 2015 and 2016 along the seashore of Latvia from Pape (near Lithuanian border) to Ainaži and Ikla (Estonia) (EvarTsBunders et al., 2016). Inland, the sites potentially suitable for the growth of the Corispermum taxasand and gravel quarries, sandy shores of lakes and rivers, railway sections, sandy ruderal sites, etc. were randomly surveyed in different regions of Latvia in 2008-2019. The western part of Lithuania - Palanga, Klaipeda Region and the Curonian Spit as well as
Poland Pomerania province (Vistula Spit, Gdansk Region), were surveyed during the vegetation season of 2019. All our collected and cited herbarium specimens were deposited at the Herbarium of Daugavpils University, Institute of Life Sciences and Technology (DAU) and registered in the database of the Herbarium Universitatis Daugavpilensis (Evarte-Bundere et al., 2020).

The comparison of diagnostic characters for all Corispermum species was based on herbarium specimens collected in Latvia as well as on different relevant taxonomic literature (StrazdiN̦š, 1985; AELlen \& Akeroyd, 1993; Mosyakin, 1996; Sukhorukov, 2007, 2014). The status of the Corispermum species whether the taxon is native or alien to Latvia was determined. In this study, we used widely accepted terms alien plant and casual alien plant clearly defined by different authors (RICHARDSON et al., 2000; PyšeK et al., 2004; Stace \& Crawley, 2015). Casual alien plants are species that may flourish and even reproduce occasionally in an area, but which do not form self-replacing populations, and which rely on repeated introductions for their persistence.

Species distribution maps were prepared by applying the square method, which is related to the geographical coordinates, where one square corresponds approximately to $7.6 \times 9.3 \mathrm{~km}$ or $71 \mathrm{~km}^{2}$ for Latvia (TABAKA et al., 1980) and join with $10 \times$ $10 \mathrm{~km}$ square grid for Estonia and Lithuania. The maps were made to enable the analysis of the age of localities, the dynamics of species distribution across the Baltic States. Species spread studies involve two following phases:

1. The turn of the 19th-20th centuries until 1990, which includes: World War I and II; years of Soviet occupation, when the Baltic States experienced significant changes in land management and transport flows, mainly railway transport flows from the East.

2. Since 1991 to nowadays, when land management methods and traffic flow directions have changed again (Fig. 1).

For annual plants, we can regard the localities as topical if they have been surveyed and the plant in it has been identified within the last 20-25 years. Therefore, the actual distribution of the species can be discussed only according to the locality maps made since 1990.

The authors of the taxa were mentioned in ac- 

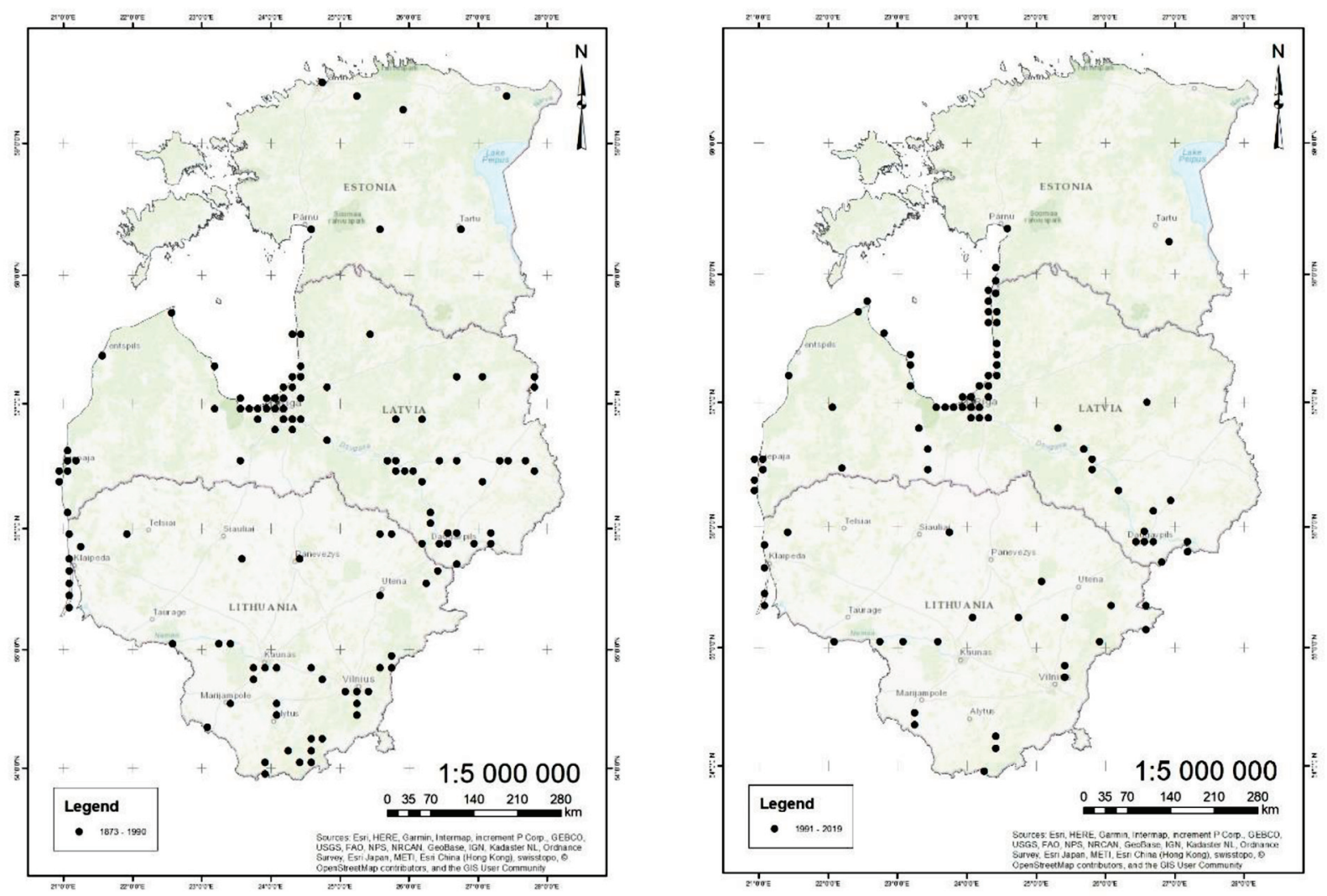

Fig. 1. Distribution of the genus Corispermum in the Baltic States according to all available herbaria collections. Left map localities known until 1990, right map - localities known or verified since 1991

cordance with a list of authors of plant names (BRUMMIT \& Powell, 1992). The list of the Corispermum species in the text was arranged in the alphabetical order. The problem of hybridisation in the genus Corispermum is not discussed in detail in this paper.

\section{RESULTS}

There are four species verified by herbarium materials currently known in the Baltics States: Corispermum hyssopifolium L., C. declinatum Steph. ex Iljin, C. intermedium Schweigg. and C. pallasii Steven.

Corispermum declinatum Steph. ex Steven, 1814. Mém. Soc. Imp. Naturalistes Moscou v. 334.

An annual psammophytic plant, native area Mongolia, Russia (S Siberia) and adjacent part of China, locally naturalised in E Europe. In the Baltic States, it is considered to be a rare alien species, in Estonia - probably, extinct. Typical habitats are dry, sandy roadsides, railways, sand and gravel quarries, disturbed embryonic dunes on seashore, sandy lakeshores, and ruderal places.

The species is easily identifiable by its very distinctive fruit, the length of which twice exceeds the width, having a peculiar shape, with almost no wing it is narrow in shape only at the tip of the fruit (Fig. 2). The inflorescence is narrow, not wider than the rest of the stem. Perianth segments are present in all flowers.

First collected herbarium materials in the Baltic States were from Estonia - Antsla, railway embankment (Leg. V. Kask, TAA, 1957), Latvia Rīga, Daugavgrīva, railway (Leg. K. Kupfer, RIG, 1898; TU, LE, 1900) and Lithuania - Palanga (Leg. K. Brundza, BILAS, 1959). At the time of the publication of the list of vascular plants in Lithuania (GudžInSKAS, 1999), C. declinatum had already been collected in the herbarium of Lithuania, and identified as C. declinatum by J. Strazdiņš in 1985. Despite this, the species was not included in this work and published later as a species new to Lithuania (GudžInSKAs \& SukHorukov, 2004). 
The species has become less frequent in recent years, since 1991 it has been identified only in three localities in the Baltic States. Two localities are known in Latvia: Rīga, on railways and Daugavpils,

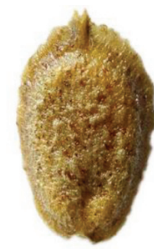

a

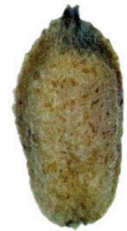

b

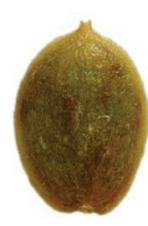

C

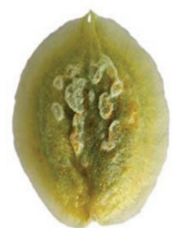

$\mathrm{d}$

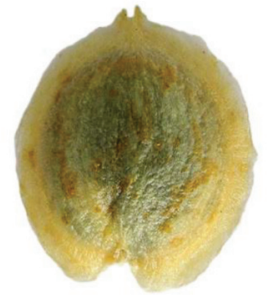

e

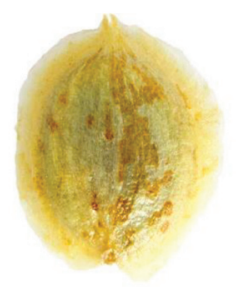

f
Fig. 2. Seeds of Corispermum species: a $-C . \times$ latvicum Rasinš, b - C. declinatum Steph. ex Steven, $\mathrm{c}-C$. hyssopifolium L., $\mathrm{d}-$ C. pallasii Steven, e - C. intermedium Schweigg., $\mathrm{f}-C$. intermedium $\times$ C. pallasii. (Bar equals $1 \mathrm{~mm}$ )

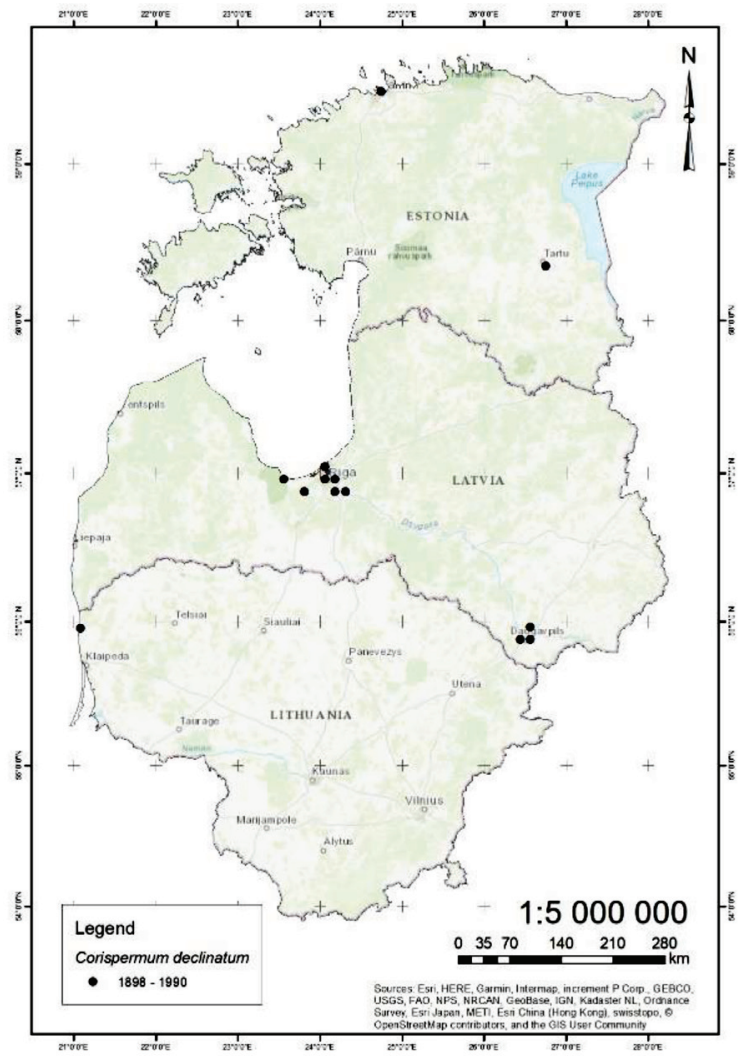

in the marshalling yard, where previously known locality was re-found in 2019 (Leg. G. Evarte-Bundere, DAU 100016, DAU 100017, DAU 100018), and one in Lithuania, where new locality was found in 2017 near Pakaršys in disturbed sandy habitat (Leg. V. Rašomavičius, DAU 10003396, DAU 10003397) (Fig. 3).

At the same time, in Belarus, the species is much more common, with about 50 herbarium specimens, also collected during recent years. The herbaria were collected in Grodno, Minsk, but most of all in Gomel, including the Dnieper River dry sandy terrace. Species is known from Braslav Region in Belarus (right at the Latvian border), where it was collected in 2010 on the oil pipeline route, which allows predicting new potential localities of this species in anthropogenic habitats in the Baltic States not only along railways.

Corispermum $\times$ latvicum Rasiňš $(C$. declinatum $\times$ C. leptopterum) (Fig. 2) - a rare hybrid, collected a few times near Sloka, in Latvia and described by famous Latvian botanist A. Rasiņš, not found during last 30 years. All current herbarium, identified

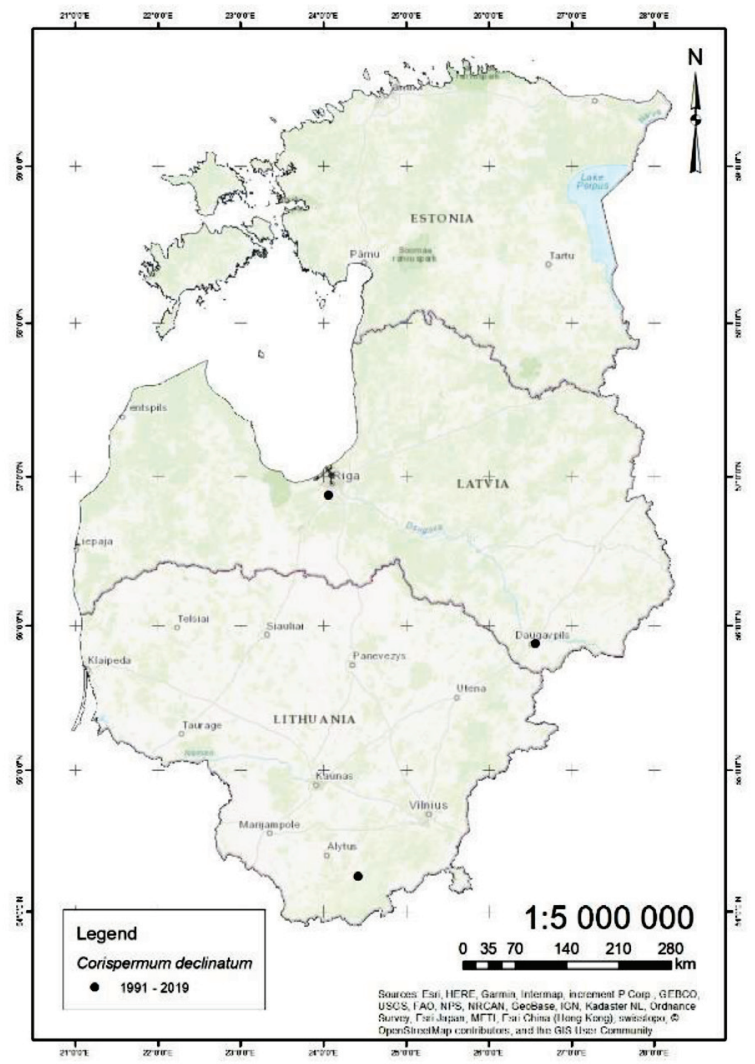

Fig. 3. Distribution of Corispermum declinatum Steph. ex Steven in the Baltic States. Left map - localities known till 1990, right map - localities known or verified since 1991 
as $C . \times$ latvicum, after our critical analysis, was reidentified as $C$. pallasi.

Corispermum hyssopifolium L. 1753, Sp. Pl.: 4.

- C. hybridum Besser ex Andrz., 1862, Univ. Izv. (Kiev) 7-8: 135.

An annual plant naturally was found in dunes and sandy spots along rivers in Central and Western Europe. Locally, it was naturalised in Eastern Europe and Western North America. In the Baltic States, it is considered to be a rare casual alien species (ephemerophyte), in Estonia not found during the last 30 years. The main habitats are roadsides, railway embankments, sand and gravel quarries, ruderal, sandy places, sandy river shores and lakeshores.

Flowers are with hypanthia, which may cause problems in distinguishing this species from more common species with hypanthium $-C$. pallasii. The most essential character of the detection is that the fruit has nearly no wing or a very narrow wing $\left(1 / 8_{-}\right.$ $1 / 10$ of the fruit), with the fruit epidermis not spotted (Fig. 2). Specimens with very narrow and translucent

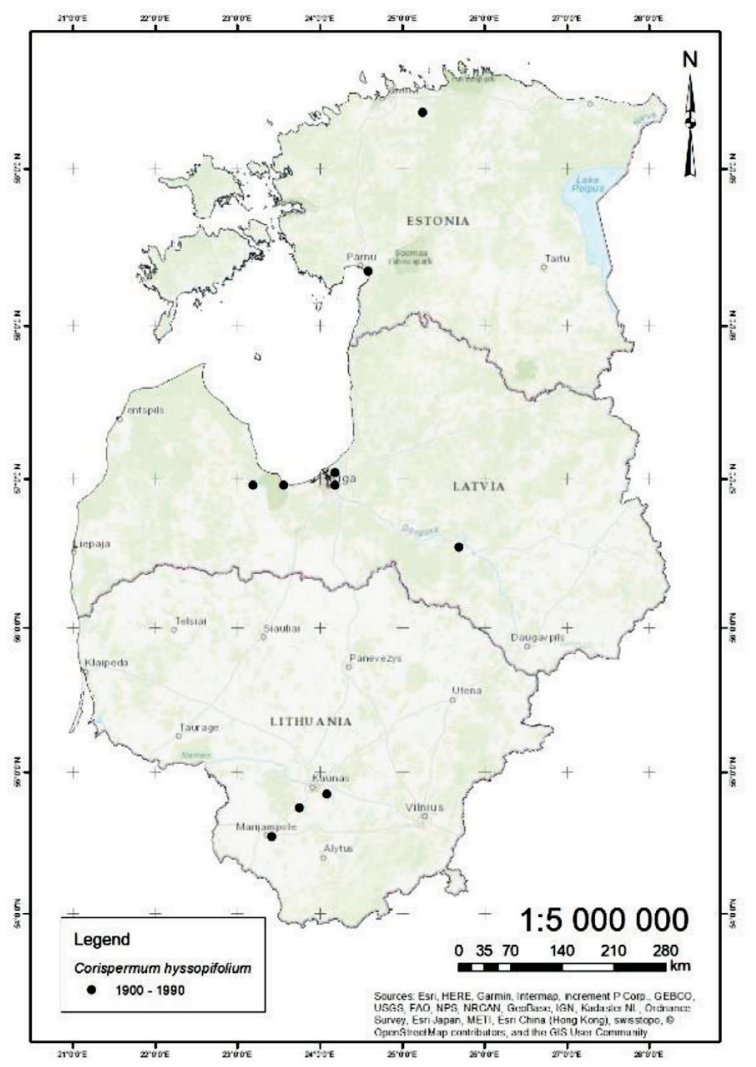

seed wings in the herbaria of the Baltic States were often identified as C. hybridum or even as C. pallasii. All other characters are similar to those of $C$. hyssopifolium, a narrow inflorescence, seeds of green colour, a perianth, which allows $C$. hybridum to be considered synonymous. The leaves are narrow, about $1 \mathrm{~mm}$ wide and long so that they can be easily confused with another similar species of $C$. nitidum.

The first collected herbarium materials in the Baltic States: Estonia - Pärnu, railway embankment (Leg. A. Remmel TU, 1967); Latvia - Rīga, Daugavgrīva, railway (Leg. K. Kupfer, RIG, 1896); Lithuania Kaunas (Leg. A. Lekavičius, BILAS, 1963). This species has also become increasingly rare in recent years, since 1991 in the Baltic States its localities have been concentrated in only two cities in Latvia - Rịga and Daugavpils, and in Lithuania - Marijampolè and Kèdainiai. After examining those mentioned above and potential localities in the Baltic Region, it has not been repeatedly found elsewhere (Fig. 4).

Having analysed the herbaria of Belarus, it can be concluded that the species is more abundant there.

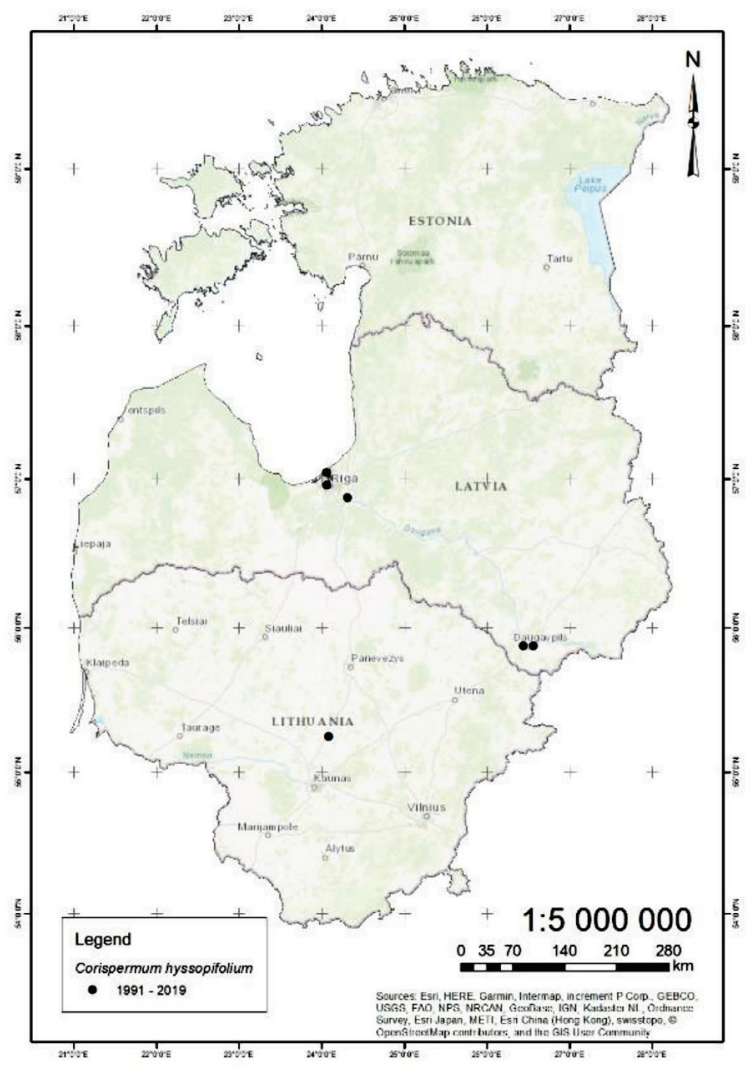

Fig. 4. Distribution of Corispermum hyssopifolium L. in the Baltic States. Left map - localities known till 1990, right map localities known or verified since 1991 
About 70-80 herbaria have been collected from all over the country, but much less in the north. Thus, only two old herbaria are from Vitebsk Region, and only 30-40 herbaria specimens come from Gomel (south-eastern Belarus). However, there has been a decline in the species in recent years there, too - the entire mass of the localities in the 70 s, with very few herbaria in the last 20 years.

Corispermum intermedium Schweigg. 1812, Koningsb. Arch. Naturw. 1: 211.

Endemic species to the Eastern Baltic Region are distributed from the Curonian Spit in Lithuania till the southern seashore of Estonia, only the autochthonous Corispermum in the Baltic Region. In the Baltic States, it is considered to be rare in Latvia, very rare in Estonia and very rare in Lithuania. Typical species for annual vegetation on embryonic shifting dunes and other coastal habitats, very rare inland - sandy places: sand quarries, roadsides, railway embankments. Most important characters for identification - at the time of fruiting plants usually turn yellow, the leaves are relatively broad, linear, the margins of leaflets are not entire, and the spikes are generally short and dense. Perianth segments are absent in nearly all flowers. Fruits are typically speckled, suborbicular, and bigger than seeds of other Baltic Corispermum species. Main differences from similar C. marschallii - erect plants, associated with halophytic soils, seed is olive green, seed wing is approximately $0.5 \mathrm{~mm}$ wide and stylodia on the seed tip are facing outwards (Fig. 2).

The first collected herbarium materials in the Baltic States: Estonia - Tartu, railway embankment (Leg. A. Remmel, TU, 1964); Latvia - Jūrmala, Asari, embryonic dunes (RIG, 1873, without collector); Lithuania - Palanga, dunes (Leg. K. Kupfer, RIG, 1898). It is certain that species can be considered as, probably, extinct in a part of the range in Lithuania the species has not been encountered for more than 30 years. More recent Corispermum studies from the Curonian Spit in Lithuania (Smiltyne, embryonic shifting dunes, the Nagliai Nature Reserve, Pervalka, embryonic shifting dunes (leg. P. Evarts-Bunders, G. Evarte-Bundere, A. Bojāre, 2019)) showed that only hybrids with $C$. pallasii or untypical specimens with no typical diagnostic characters (with more or less developed perianth in all flowers) were found.
However, new localities of $C$. intermedium are possible directly here. The situation with $C$. intermedium in Latvia looks more promising - the species has remained in Kurzeme (Western Latvia) with some localities in the area from Jūrmalciems to Liepāja, and has been known since the end of the 19th century. The main population from Vecāķi to Ainaži can be considered to be rich and stable and still not endangered, especially the populations in Ainaži and Salacgrīva. The species requires additional studies in the northern and southern parts of the distribution area to explain the distribution patterns of the species as well as conservation measures to preserve one of the few endemic plant species in the Baltic Region as long as possible. The species has no protection status in Lithuania and Estonia, in Latvia - the Red Data Book (KaBucis, 2003).

Corispermum pallasii Steven 1814, Mém. Soc. Imp. Naturalistes de Moscou 5: 336; - C. leptopterum (Aschers) Iljin, 1929. Izv. Glavn. Bot. Sada S.S.S.R. 28: 653.

- C. sibiricum auct., non Iljin: Rasiņš 1954. Latv. nez. augli 138 .

Annual psammophytic plant, native area - S Siberia, Mongolia and adjacent parts, widely naturalised in E Europe. In Latvia and Lithuania, it is the most common alien Corispermum species, in Estonia - rare alien species. Typical habitats are dry sandy roadsides, railways, sand and gravel quarries, disturbed embryonic dunes on seashore, ruderal places (Fig. 6).

The species is easily identified by several morphological characters: inflorescences are usually short and dense, at the time of fruiting, the stem and the biggest leaves turn red; perianth segments are present for most flowers. Fruits (winged nuts) are usually speckled, suborbicular and smaller than the seeds of endemic C. intermedium (Fig. 2).

The species is not homogeneous; it is subdivided into two varieties:

Corispermum pallassii var. membranaceaum (Iljin) Tzvel. The seeds with tight, non-transparent wing. The wing is approx. $1 / 4$ as wide as the seed. The leaves are approx. $2 \mathrm{~mm}$ broad. At the time of fruiting, the leaves and the stem turn red. Often found throughout Latvia and Lithuania.

Corispermum pallassii var. pallasii. The seeds with a thin, transparent wing. The wing is approx. $1 / 6$ as wide as the seed. The leaves are more expan- 

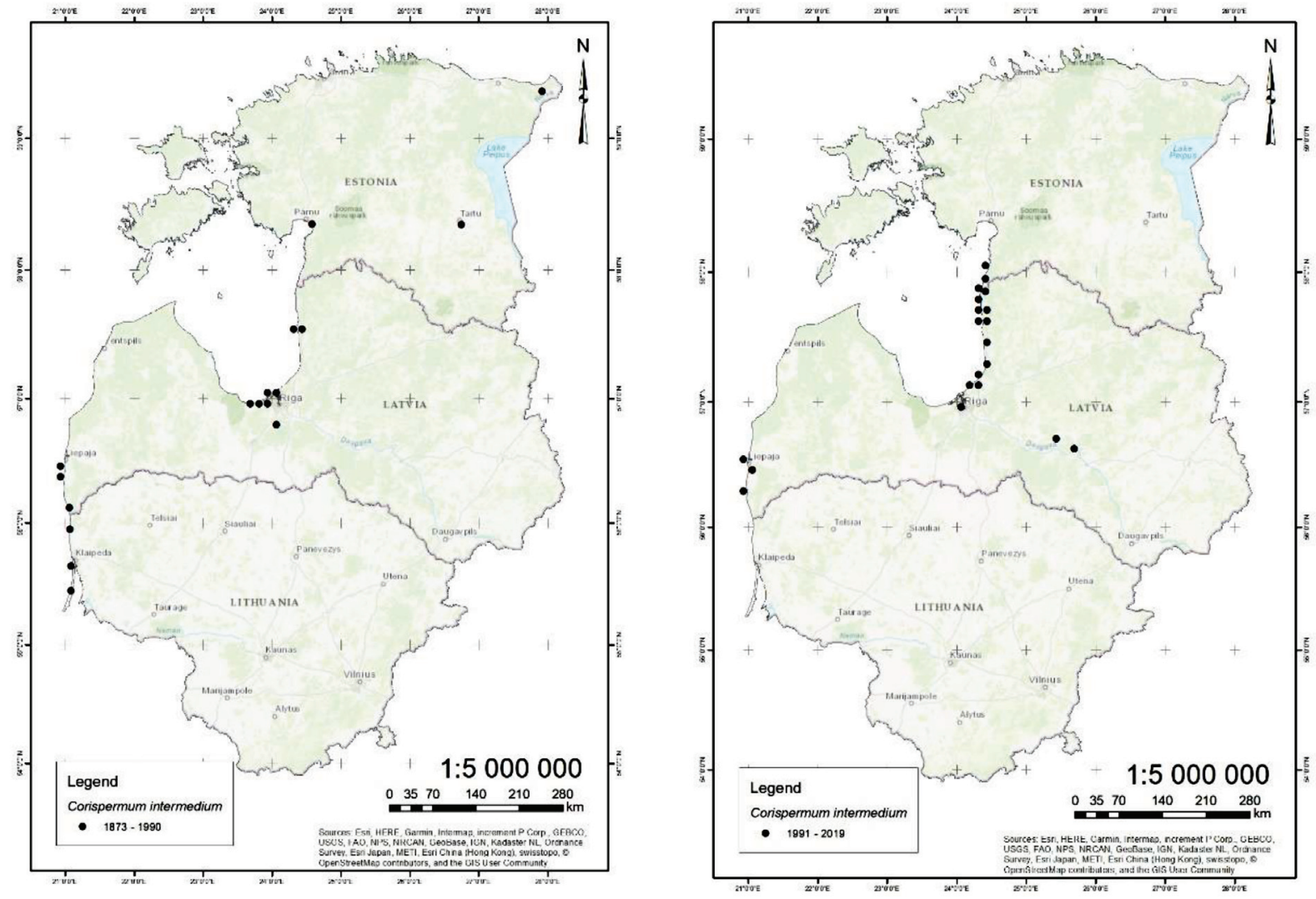

Fig. 5. Distribution of Corispermum intermedium Schweigg. in the Baltic States. Left map - localities known till 1990, right map - localities known or verified since 1991

sive than in the first variety $-2.5-3(4) \mathrm{mm}$ broad. The plants are dark green, at the time of fruiting, do not turn red. It is a rarer variety, mostly encountered along the railways. In the Baltic States, the epithet C. leptopterum (Asch.) Iljin has been used for a long time for this species, which was described as a new combination in 1929 by Iljin. C. pallasii was described as a new species in as early as 1814 (STEVEN, 1814), which is also used as an accepted, priority epithet in contemporary works. SUKHORUKOV (2014) has been investigating the issue further by comparing the initial descriptions of the two taxa. He concludes that Steven's description is too general and that Iljin's new, defined combination is more accurate and describes the species we know as $C$. pallasii more precisely, thus, calling into question the use and priority recognition of the taxon C. pallasii.

The first collected herbarium materials in the Baltic States were from Estonia - Turba village (Leg. A. Remmel, TAA, 1960), Latvia - Rīga, Brasa railway station (Leg. V. Mühlenbach, RIG, 1932) and Lithuania - Juodkrante (Leg. E. Purvinas, WI, 1932).

Having analysed the herbaria of Belarus, it can be concluded that here the species is considered to be the most common representative of the genus. It is locally massively encountered, especially in recent years. The trend is similar to that in the Baltic Region - other species are retreating; this species is aggressively occupying all appropriate niches.

\section{Other potential species of the Corispermum genus in the Baltic Region}

After assessing the presence of other potentially possible species in the flora of the Baltic States, we also analysed two main herbaria of the Republic of Belarus. The other two species of Central and SouthEastern Europe were found in the Belarusian herbaria, the locations of which were relatively close to the borders of the Baltic States and, therefore, considered potentially possible in the Baltic States. For this reason, we included these two species in the summary 

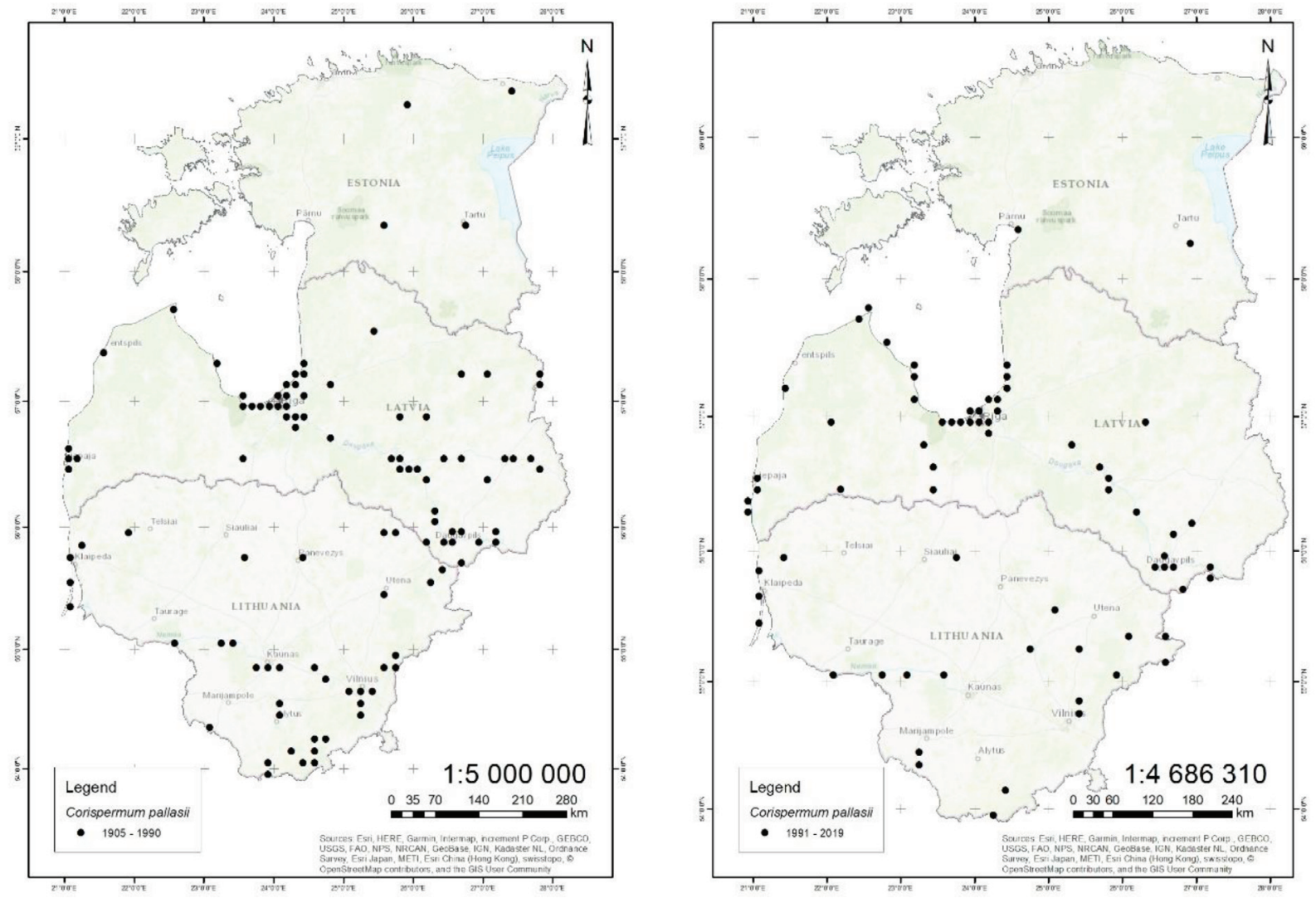

Fig. 6. Distribution of Corispermum pallasii Steven in the Baltic States. Left map - localities known till 1990, right map - localities known or verified since 1991

of morphological characteristics of the Corispermum species in the Baltic States (Table 1).

Corispermum marschallii Steven, 1814. Mém. Soc. Imp. Naturalistes Moscouv. 336.

Annual psammophytic plant with native area in C, E Europe and W Siberia. In Latvia, the species is indicated in old herbarium materials, in Lithuania as a potential species (SNARSKIS, 1954). However, during our research, this species was not identified in the earlier Baltic herbarium collections. Certain herbaria identified mistakenly in the first half of the 20th century as $C$. marschallii in the LATV herbarium are typical $C$. pallasii specimens - they have a perianth. In contrast, they have no broad, curled seed wing.

The occurrence of the species may not be excluded in the Baltic Region until now, and attention should be paid to the Corispermum specimens with absent perianth segments in nearly all flowers and with a broad seed wing. Habitually it is similar to C. pallasi - the species is characterized by a short, dense inflorescence, but the perianth is absent, and the seed has an extensive, filmy and slightly wavy wing (Table 1). An excellent distinguishing character from another similar species $C$. intermedium - different biotopes (not direct seashore and halophytous), habitually - stem is ascending or prostrate) seed is yellowish-brown, seed wing is relatively broad, $0.8-1$ (1.2) $\mathrm{mm}$ wide). Stylodia are facing inward (Fig. 2). Another good diagnostic character is a cross-cutting of seed - distinctly convex, nearly hemispherical seed of $C$. intermedium and flat, not convex seed of C. marschallii. In general, it is very difficult or even impossible to distinguish between these two species (A. Sukhorukov, personal communication).

Analysis of the herbaria of Belarus shows that the species is scarce here as well - only a few specimens have been collected from one site - Saligorsk (MSK 95869), which coincides with the literature data that species is rare throughout E Europe (SukHORUKOv, 2014).

Corispermum nitidum Kit. et Schult. 1814, Oestr. Fl., ed. 2 1:7. 


\begin{tabular}{|c|c|c|c|c|c|c|}
\hline 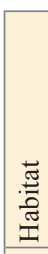 & 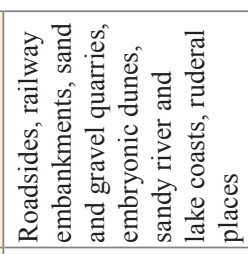 & 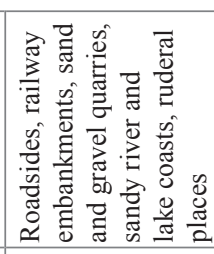 & 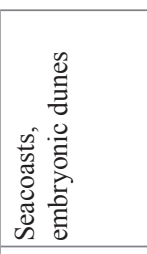 & 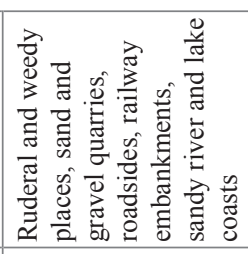 & 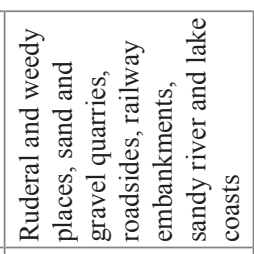 & 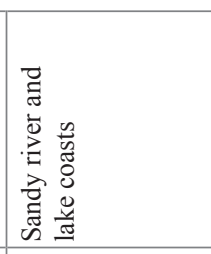 \\
\hline 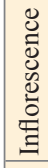 & 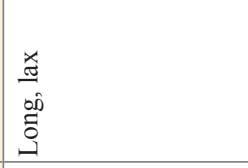 & 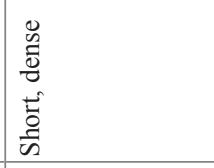 & & 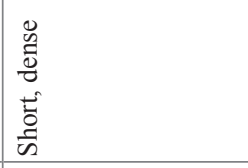 & 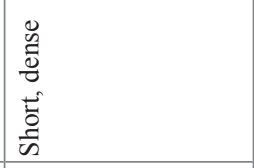 & 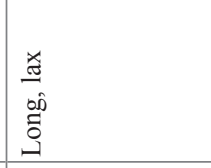 \\
\hline . & 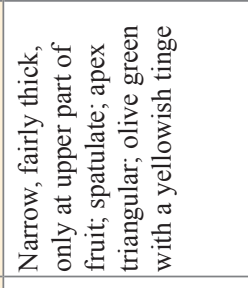 & 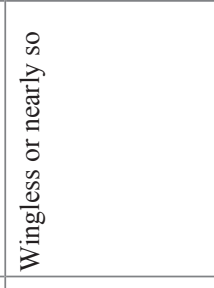 & 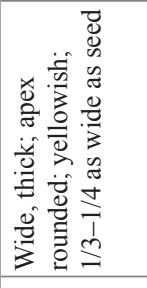 & 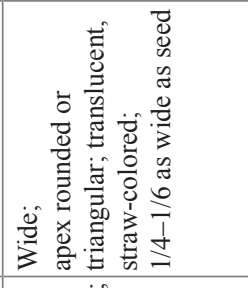 & 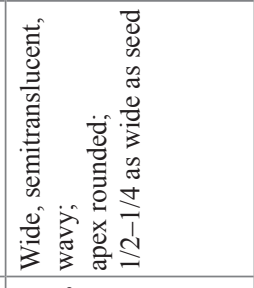 & 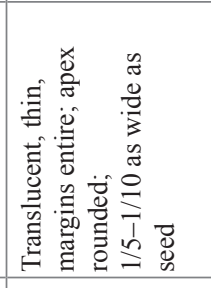 \\
\hline 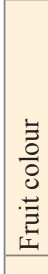 & 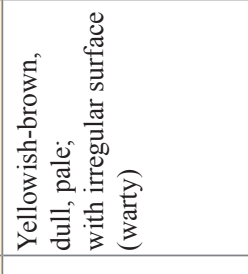 & 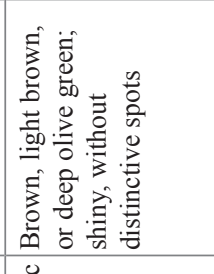 & 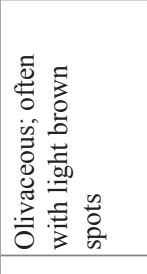 & 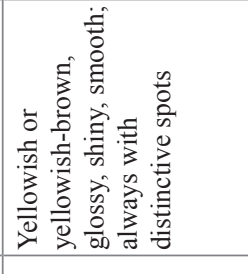 & 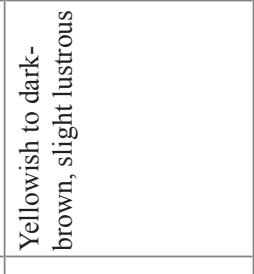 & 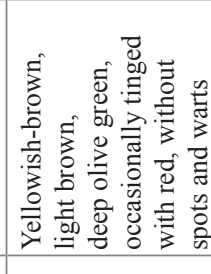 \\
\hline 壱 & 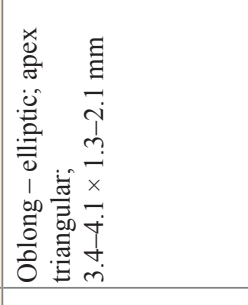 & 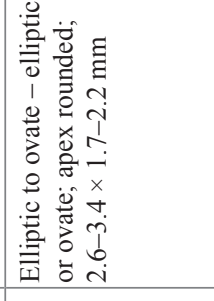 & 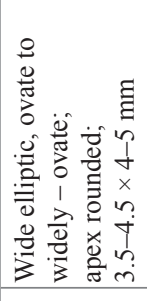 & 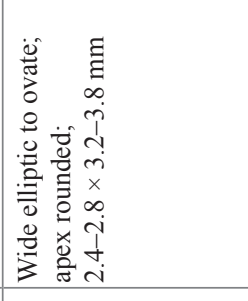 & 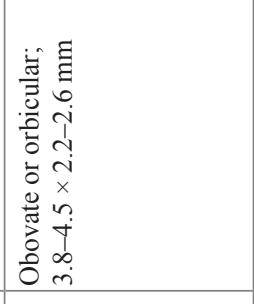 & 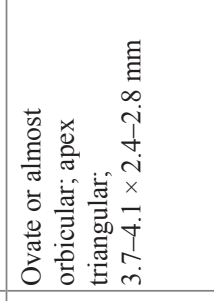 \\
\hline 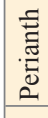 & 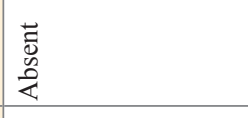 & 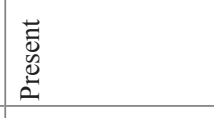 & 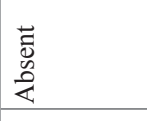 & $\begin{array}{l}\overrightarrow{0_{0}} \\
\dot{0} \\
\dot{0}\end{array}$ & 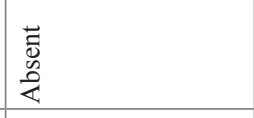 & 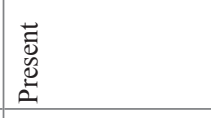 \\
\hline 岕 & 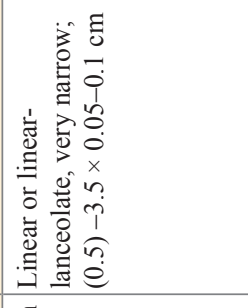 & 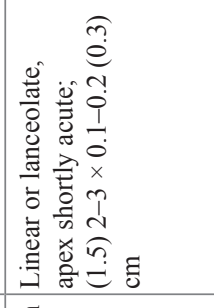 & 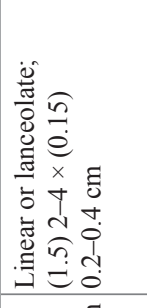 & 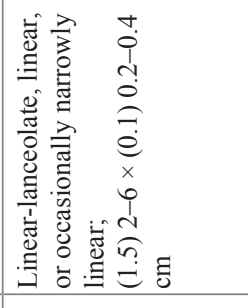 & 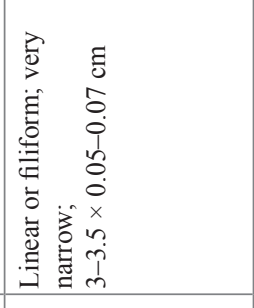 & 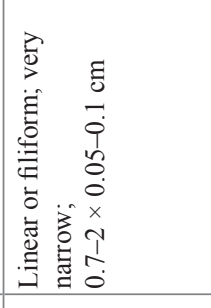 \\
\hline 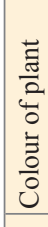 & 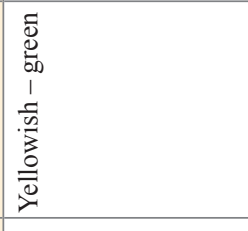 & 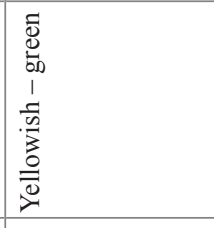 & 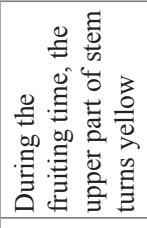 & 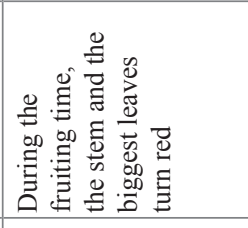 & 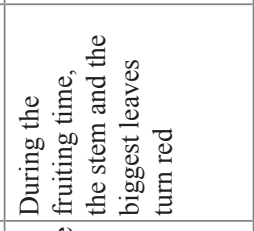 & 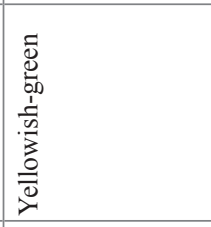 \\
\hline $\begin{array}{l}\text { ज्ञ } \\
\text { क् }\end{array}$ & 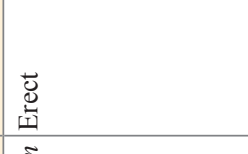 & 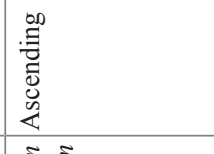 & 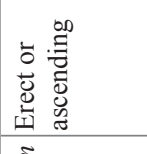 & 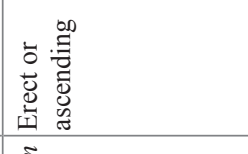 & 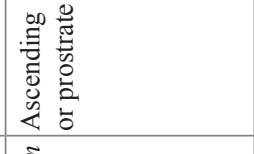 & 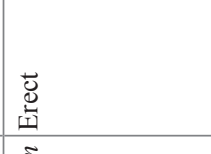 \\
\hline.$\frac{\mathscr{d}}{0}$ & 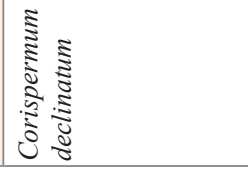 & 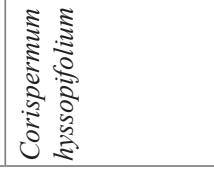 & 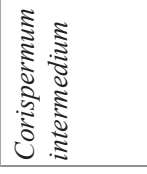 & 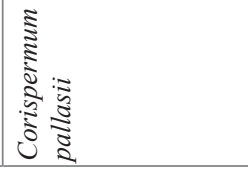 & 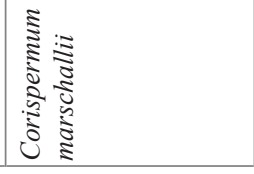 & 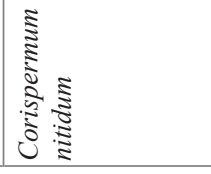 \\
\hline
\end{tabular}


Annual psammophytic plant. The plant has narrow, cylindrical leaves, a well-visible perianth, and a fruit wing with a leathery, opaque wing. Inflorescence is narrow and long, not wider than other shoots, seeds with a leathery wing $(1 / 5-1 / 10$ of the fruit wing's width). The species was only mentioned in the literature in Latvia (KUPFFER, 1924) as well as in the herbarium materials collected by K.R. Kupffer in Riga, Daugavgrivva port, on the railway (Ad viam ferream inter horrea portus Hafendamm. Advena. No 12764, 04.09.1900, duplicates in TU, LE).

Species was found later in herbaria with various synonyms, including $C$. nitidulum, however, all previously identified specimens in the Baltic herbaria correspond to C. hyssopifolium, less frequently C. declinatum or C. pallasii.

At the same time, the species is encountered in the Republic of Belarus. Herbarium material (MSK, No. 160142) was collected in 2010 on the sandy shore of Lake Drisvyaty (near Braslav, NW Belarus), about $20 \mathrm{~km}$ from the Latvian border.

\section{DISCUSSION}

\section{An overview of the problems of the Corispermum species}

Throughout the distribution area of the genus Corispermum, botanists face a problem of precise identification of the Corispermum taxa. For example, having analysed the herbarium collections in Canada, it has been concluded that the species in most cases are misidentified (RoBson, 2010). Gaining more and more knowledge about the characters that are important for detection, the botanists in China have reached a similar conclusion - the taxonomic composition of Chinese Corispermum will change as several species are hastily added to the area (ZHU et al., 2003). Our study on herbaria and available scientific literature in the Baltic States also lead to similar conclusions.

During the botanical studies, the number of the Corispermum species in the Baltic States has gradually increased. Initially, only one species had been described in the Baltic States $-C$. intermedium (Fleischer, 1839; Klinge, 1882; Bitckis, 1923, 1926, 1935), followed later by C. hyssopifolium, first mentioned by A. RASIN̦š (1946). In the main floristic works during the Soviet time, only one or two species have been mentioned in each country (PẼTERSONE
\& Birkmane, 1958; Snarskis, 1954; Galenieks (ed.), 1955; Eichwald et al., 1971). In more recent works, six species of the Corispermum genus have been recorded in the territory of the Baltic States (STRAzDIN̦Š 1985, 1993). Our research shows that there are only four species verified by herbarium materials currently known in the Baltics States.

\section{Floristic status and distribution dynamics of the Corispermum species in the Baltic States}

Corispermum intermedium is considered as only native and endemic species in the Eastern Baltic Region. Its habitats are related to annual vegetation on embryonic shifting dunes and other coastal habitats. It is known from all Baltic States. Still, it can be considered as, probably, extinct in Lithuania - the species has not been encountered for more than 30 years. Only hybrids with $C$. pallasii have been found. The largest and most stable population of $C$. intermedium is known from the Eastern shore of the Gulf of Riga in Latvia.

It should be noted that back in 2007 , no $C$. intermedium endemic to the Baltic Region was identified and included in the list of flora of Estonia. It has been argued that $C$. intermedium distribution area ends with the administrative border of Latvia, which, of course, seems strange. In 2016, the field studies along the seacoast of Estonia from Ikla to Häädemeeste resulted in the discovery of $C$. intermedium as a new species in the Estonian flora (EvARTS-BundERs et al., 2016). The question that remains open for discussion is whether this species has recently entered the coast of Estonia or it has always been there, misidentified or undetected. Herbarium research revealed that C. intermedium had been present inland in Estonia since at least the 1960s (A. Remmel, 1964, Tartu, TU) (Fig. 4).

Other three species also prefer dry, but disturbed habitats. Those are ephemerophytic C. hyssopifolium and $C$. declinatum - both have become less frequent in recent years (Figs 3, 4). The rarest Corispermum species in the Baltic States C. declinatum is known only from three current localities in Latvia and Lithuania. The fact that this species is still present in Lithuania has been confirmed by the only collection of recent years (leg. V. Rašomavičius, det. P. Evarts-Bunders, 2017, BILAS, DAU) (Fig. 3). 
Corispermum pallasii is considered as potentially invasive and observed in the region with increasing distribution dynamics.

\section{Confusing species mentioned in the flora of the Baltic States}

In the manual of weed seeds (RAsinsš, 1954), Asian species C. sibiricum Iljin is included. Fruit of C. sibiricum was photographed with 10-fold magnification in this work. In our opinion, it is a typical fruit of $C$. pallasii. A. Rasinš corrected his mistake in the edition of the Latvian SSR vegetation (Volume III) and admitted that the previously published $C$. sibiricum had been $C$. leptopterum. Besides, Rasinsš has highlighted the urgent need for a revision of the genus Corispermum (RAsıșš, 1960). C. sibiricum has also been mentioned in the issue of Eesti NSV Flora, mentioned in the vicinity of Narva, on the railway (EICHWALD et al., 1971). This is likely a misidentification of this species, as C. pallasii is known also from Narva and its vicinity. In Lithuania, C. sibiricum is unlikely to be identified, either. This species is mentioned in the Lithuanian literature in the list of flora of vascular plants (GUDžINSKAS, 1999). No specimens of $C$. sibiricum were found in the most important scientific herbarium collections in the Baltic States. Assuming that $C$. sibiricum may come to the Baltic States from Russia, the question arises why this species is not included in the flora of the north-western part of Russia (Mosyakin, 1996; Tzvelev, 2012), which directly borders the Baltics.

J. Strazdinš mentions a new species to the flora of Latvia and later Estonia - C. algidum Iljin (StRAzDinsš, 1985, 1993), despite having listed in his publication at least four morphological differences between the type herbarium (Komarov Institute, Russia) and plants found in Latvia. Species identification characters: the stem of C. algidum is red in colour, the leaves are narrow, usually about $1.5 \mathrm{~mm}$, and the margins of the leaves are curled up. Inflorescence is short and dense, spicate, more expansive than the rest of the stem, and hypanthium is not developed, seeds with a thin, translucent wing (1/4-1/6 of the total width of the fruit) and at the tip is not divided into two separate wings, usually not spotted.

The problem is most likely to be found in the rather general description of C. algidum made by Iljin. J. Strazdiņš has based his decision on such char- acters as fruit spotting, stem colour, and plant length, which are nowadays recognised as widely varying characters and are not secure for species identification (Strazdinšs, 1993; Priedītis, 2014). J. Strazdiņš has identified this species in Latvia as a rare, alien species (Daugavpils, Rīga, railways of other large cities), explaining the distribution of $C$. algidum in Latvia by the fact that the species is encountered along railway lines coming from the east, which is an important seed transfer vector. Distribution maps of the European flora atlas (JALAS \& SUOMINEN, 1980) have confirmed that the distribution area of C. algidum is far to the North - river basins flowing into the White Sea - north of the Karelian Isthmus (Mosyakin, 1996). According to the data from Euro+Med PlantBase distribution maps, doubts arise from the fact that $C$. algidum is only encountered in the north of Russia as well as in two Baltic States, Latvia and Estonia, although there is a large area between these ranges, where $C$. algidum is not identified (Uotila, 2011).

In response to this problem, several herbaria collected in Latvia (DAU) in recent years, corresponding to a typical species identified by J. Strazdiňš as C. algidum, were sent to St Petersburg Botanical Institute, where one of the specialists in the Corispermum genus, A. Sukhorukov, undoubtedly identified these specimens as $C$. intermedium. It is probable that J. Strazdiņš's desire to classify inland $C$. intermedium as a new species $-C$. algidum - is due to "botanical stereotypes" about plant distribution, namely that $C$. intermedium may only be found on the seacoast. However, this species is also encountered inland in the Baltic States (Fig. 4), where the identified specimens are morphologically variable, which is probably due to the hybridisation of the species, especially in disturbed habitats.

The list of Estonian flora published in 1998 (KUUSK \& KUKK, 1998) includes two species - C. hyssopifolium and C. sibiricum. However, C. algidum, along with several other Corispermum species: C. declinatum, C. hyssopifolium and C. leptopterum, are described in the Estonian plant identification guide (LEHT et al., 2007). Apparently, the occurrence of $C$. algidum in Estonia was unclear. The herbarium analysis performed during this study confirmed that all specimens of the Estonian and Latvian herbaria previously identified as $C$. algidum (in most cases 
determined by J. Strazdinšs) after re-examination were identified as $C$. pallasii, $C$. intermedium or more often as hybrid $C$. intermedium $\times C$. pallasii. Some specimens were unidentifiable, because they were collected without seeds (sterile).

The list of vascular plants of Latvia (GAVRILOVA \& Šulcs, 1999) includes C. orientale Lam., misrepresentation of which was already explained by J. Strazdinš in 1985 - the herbarium of the species is not found, therefore, the presence of the species in Latvia and the Baltic States is doubtful and most likely to be mistaken. Since the description of the species, researchers have associated the name $C$. orientale with plants morphologically close to $C$. hyssopifolium, but having wingless fruits. Still, now this name has been proposed to be rejected as unclear and misunderstood (SUKHORUKOV, 2010).

The detection and identification of morphological boundaries of $C$. hybridum have also led to confusion. Currently, the species is considered to be synonymous with $C$. hyssopifolium or, more rarely, an intra-species taxon. Thus, when analysing the BILAS herbarium collection in Lithuania, the herbarium specimens identified as C. hybridum were found to be either $C$. pallasii or $C$. intermedium or were of poor quality and, therefore, unidentifiable. However, at the Institute of Biology of the University of Latvia (LATV), where several such herbaria, formerly known as C. hybridum, were stored, they all corresponded to C. hyssopifolium.

In Lithuanian literature, $C$. marschallii is mentioned as probably encountered (SNARSKIS, 1954; GUDŽINSKAS, 1999). Lithuania has a relatively large collection of Corispermum herbaria, but this species was not identified during the herbaria study. We believed that the prevalence of $C$. marschallii in Lithuania is very probable, as this species has been encountered in neighbouring countries - Belarus and Poland (UotiLA, 2011). The species has a relatively southern range and is, therefore, most likely to be identified in the southern part of Lithuania.

\section{ACKNOWLEDGEMENTS}

We are grateful to the all specialists and curators for a kind permission to work with herbarium collections: Estonia - T. Kull, T. Kukk (Estonian University of Life Sciences, Institute of Botany and
Zoology, TAA), Ü. Reier (Tartu University, Natural History Museum, TU), Latvia - I. Rūrāne (University of Latvia, Institute of Biology, Laboratory of Botany, LATV), J. Meža (University of Latvia, Museum of Botany, RIG), Lithuania - V. Rašomavičius (Nature Research Centre, Institute of Botany, BILAS), M. Rasimavičius (Vilnius University, WI), Republic of Belarus - D. Dubovik, A. Skuratovich (National Academy of Sciences of Belarus, Institute of Experimental Botany, MSK), V. Tikhomirov, D. Dzhus (Belarusian State University, Department of Botany, MSKU) and P. Efimov, G. Konechnaya (Russian Academy of Sciences, Komarov Botanical Institute, LE). We express gratitude to A. Sukhorukov (Moscow State University) for assistance in identification of some unclear Corispermum specimens and everyone, who has contributed to the collection of the Corispermum herbarium material. We are also grateful to the reviewers for valuable comments that helped to improve the paper. The work is supported by DU project No. 4-25/13 "Taxonomic revision of bugseed (genus Corispermum L.) in the Baltic States".

\section{REFERENCES}

Aellen P., Akeroyd J.R., 1993: Corispermum L. In: Tutin T.G., Burges N.A., Chater A.O., EdMONDSON J.R., HeYwood V.H., Moore D.M., VALentine D.H., Walters S.M. \& Webb D.A. (eds), 1993: Flora Europaea ( $2^{\text {nd }}$ edition), 1: 119-120. Cambridge.

Bitckis J., 1923: Latvijas augu noteicējs. - Cēsis.

BitCKIS J., 1926: Latvijas augu noteicējs. - Cēsis un Rīga.

BitcKis J., 1935: Latvijas augu noteicējs. - Rīga.

Brummitt R.K., Powell C.E., 1992: Authors of plant names. - Kew.

Dolnik C., Peyrat J., Volodina A., Sokolov A., 2011: Neophytic Corispermum pallasii Stev. (Chenopodiaceae) invading migrating dunes of the southern coast of the Baltic Sea. - Polish Journal of Ecology, 59: 95-103.

Dubovik D.V., Tret'yakov D.I., SkURATOVich A.N., Parfenov V.I., ArhipenKo N.A., 2011: Biologičeskoe raznoobrazie nacionalnogo parka "Braslavskie ozera": Sosudistye rastenija. Minsk. 
Dubovik D.V., Skuratovich A.N., Tret’yakov D.I., Parfenov V.I., Dzhus M.A., Tihomirov V.N., SavChUK S.S., Sautkina T.A., 2014: Biologičeskoe raznoobrazie nacionalnogo parka "Naročanskij": Sosudistye rastenija. - Borisov.

Eichwald K., Kalamees K., Kask M., Krall H., Kuusk V., Masing V., Paivel A., Puusep V., Remmel A., Tals S., Tamm U., Viljasoo I., 1971: Eesti NSV Floora. - Tallin.

Evarte-Bundere G., Evarts-Bunders P., KrasnaPOL̦SKA D., SVILĀNe I., 2020: Herbarium Universitatis Daugavpiliensis. Daugavpils University. Occurrence dataset https://doi.org/10.15468/owig1t accessed via GBIF.org on 2020-02-04.

Evarts-Bunders P., Evarte-Bundere G., Bojāre A., Krasnopolśska D., Nitcis M., 2016: Native bugseed species Corispermum intermedium Schweigg. and alien Corispermum pallasii Steven in coastal habitats of Latvia - new knowledges of distribution and invasions. - Acta Biologica Universitatis Daugavpiliensis, 16(2): 165-174.

Fleischer J.G., 1839: Flora der deutschen Ostseeprovinzen Esth-, Liv-, und Kurland, - Mitau.

Galenieks P. (ed.), 1955: Latvijas PSR flora. II. Rīga.

Gavrilova G.., Šulcs V., 1999: Latvijas vaskulāro augu flora. Taksonu saraksts. - Rīga.

GUDŽINSKAS Z., 1999: Lietuvos induočiai augalai. Vilnius.

GuDŽINSKAS Z., 2000: Conspectus of alien plant species of Lithuania. 13. Chenopodiaceae. - Botanica Lithuanica, 6(1): 3-16.

GudžInSKas Z., SukHorukov A.P., 2004: New and critical Chenopodiaceae taxa in Lithuania and Kaliningrad region. - Botanica Lithuanica, 10(1): 3-12.

ILJIN M.M., 1929: Corispermi generis species novae. Izvestija Glavnogo Botaničeskogo Sada SSSR, 28(5/6): 637-654.

ILJIN M.M., 1949: Chenopodiaceae Less. - In: DoROZHKIN N.A. (ed.), Flora BSSR, 2: 160-207. Minsk.

Jalas J. \& Suominen J. (eds), 1980: Atlas Florae Europaeae. Distribution in vascular plants in Europe. 5. Chenopodiaceae to Basellaceae. - Helsinki.

Kabucis I., 2003: Corispermum intermedium Schweigg. - In: ANDRUŠAitis G. (ed.), Red Data Book of Latvia. Vascular plants, 3: 484-485. - Rīga.
KLINGE J., 1882: Flora von Est- Liv- und Curland. Reval.

KLokov M.V., 1960: O Dneprovskix i nekotoryx drugih vidax roda Corispermum L. - Botaničeskie Materialy Gerbarija Glavnogo Botaničeskogo Sada SSSR, 20: 90-136.

Klokov M.V., Krasnova A.N., Vynajev G.V., Tretyakov D.I., 1981: Horologičeskie i taksonomičeskie zametki o belorusskix verbljudkax (Corispermum L.). - Novosti sistematiki vysšix nizšix rastenija: 29-37.

KuPfFER K., 1924: Eine Reihe bemerkenswerte Pflanzen. - Korrespondenzblatt des NaturforscherVereins zu Riga, 58: 39-40.

Kurtto A., 2001: Corispermum L. - In: Jonsell B. (ed.), Flora Nordica, 2: 49-50. - Stockholm.

LEHT M. (ed.), 2007: Eesti taimede määraja. - Tartu. Mirek Z., Piekoś-Mirkowa H., Zając A., Zając M., 2002: Flowering Plants and Ptreridophytes of Poland. A checklist. - Kraków.

Mossberg B., Stenberg L. 2010: Den nya nordiska Floran. Bonnier fakta. - Inbunden.

Mosyakin S.L., 1996: Corispermum L. - In: Tzvelev N.N. (ed.), Flora Europae Orientalis, 9: 63-69. - St Petersburg.

Mosyakin S.L., 2003: Systematics, phytogeography and genesis families Chenopodiaceae Vent. Dr. Sci. (Biol.) Dissertation. - Kyiv.

Pētersone A. \& Birkmane K., 1956: Latvijas PSR augu noteicējs. - Rīga.

Priedītis N., 2014: Corispermum. - In: Latvijas augi. Enciklopēdija: 55-56 - Rīga.

Pyšek P., Richardson D.M., Rejmánek M., WebSter G.L., Williamson M., Kirschner J., 2004: Alien plants in checklists and floras: towards better communication between taxonomists and ecologists. - Taxon, 53(1): 131-143.

Rasin̦š A., 1946: Corispermum L. - In: Bitckis J. (ed.), Latvijas augu noteicējs: 147. - Rīga.

RAsıN̦Š A., 1954: Latvijas PSR nezāḷu augḷi un sēklas. - Rīga.

RASIN̦Š A., 1960: Kritiskas piezīmes par Latvijas PSR augstāko augu floras jauniem un maz pazīstamiem taksoniem. - In: Latvijas PSR veǵetācija, 3: 11147. - Rīga.

Richardson D.M., Pyšek P., Rejmánek M., BarBour M.G., Panetta F.D., West J., 2000: Naturalization and invasion of alien plants: concepts 
and definitions. - Diversity Distributions, 6: 93107.

RoBson D.B., 2010: An analysis of the distribution, ecology, and status of bugseeds (Corispermum) in Canada. - Canadian Field-Naturalist, 124(3): 246-255.

SNARSKIS P., 1954: Vadovas LTSR augalams pažinti. - Vilnius.

Stace c., Crawley m., 2015: Alien plants. - London.

Starcs K., 1936: Beiträge zur Kenntnis der Verbreitung und Formenkreise der Dicotyledonen Lettlands. Salicaceae - Papaveraceae. - Acta Horti Bot. Univ. Latv., 1934/35, 9/10: 101-142.

Steven C., 1814: Observationes in plantas Rossicas et descriptiones specierum novarum. Mémoires de la Société Impériale des Naturalistes de Moscou, 5: 334-356.

StrazdiN̦Š J., 1985: Corispermum L. - In: TABAKA L. (ed.), Flora i rastitelnost Latvijskoj SSR. Vostočno-Latvijskij geobotaničeskij rajon, 154165. - Riga.

Strazdinš̌ J., 1993: Corispermum. - In: LAasimer L., Kuusk V., Tabaka L., Lekavičius A. (eds), Flora of the Baltic Countries, 1. - Tartu.

SukHorukov A.P., 2007: Fruit anatomy and its taxonomic significance in Corispermum (Corisper- moideae, Chenopodiaceae). - Willdenowia, 37: 63-87.

Sukhorukov A.P., 2010: Proposal to reject the name Corispermum orientale (Amaranthaceae). - Taxon, 59(6): 1896-1897.

SukHoRukov A.P., 2014: The carpology of the Chenopodiaceae with reference to the phylogeny, systematics and diagnostics of its representatives. - Tula.

Tabaka L., Ku,aviña G., Fatare I., 1980: Metod kartirovanija flory Latvijskoj SSR i ego izpolzovanie pri sostavlenii „Atlasa flory Evropy”. - In: Tiкномirov V. (ed.), Kartirovanie arealov vidov flory Evropeiskoj časti SSSR, 21-24. - Moscow.

Tzvelev N.N., 2012: Corispermum L. - In: TzveLEV N.N. (ed.), Conspectus florae Europae Orientalis. Consociatio editionum scientificarum KMK, - Mosqua, 290-293.

Uotila P., (2011- onward): Chenopodiaceae (pro parte majore). - In: Euro+Med Plantbase - the information resource for Euro-Mediterranean plant diversity. http://ww2.bgbm.org/EuroPlusMed/ PTaxonDetail.asp?NameCache $=$ Corispermum

Zhu G.L., Mosyakin S.L., Clemants S.E., 2003: Chenopodiaceae. - In: Wu Z.Y., RAven P.H., Hong D.Y. (eds), Flora of China, 5: 351-414. - St Louis.

\section{CORISPERMUM L. (AMARANTHACEAE) GENTIS BALTIJOS ŠALYSE}

\section{Pēteris Evarts-Bunders, Gunta Evarte-Bundere, Maija Medne, Aiva Bojāre, Dana Krasnopol̦SKa, Inita SVILĀNe}

\section{Santrauka}

Straipsnyje pateikiami duomenys apie Corispermum rūšių taksonominę ịvairovę ir paplitimą bei jų dinamiką Baltijos šalyse per pastaruosius šimtą metų. Buvo atlikti lauko tyrimai ir herbariumų analizè. Išanalizuota visų žinomų Corispermum rūšių paplitimo dinamika, lyginant jų radavietes dviem laikotarpiais: iki $1990 \mathrm{~m}$. ir nuo $1991 \mathrm{~m}$. iki šių dienų. Herbariumų medžiagos analizè patvirtino, kad šiuo metu Baltijos šalyse yra keturios patikrintos genties rūšys: Corispermum hyssopifolium, C. declinatum, C. intermedium ir C. pallasii. C. intermedium yra vienintelè endeminè rūšis rytiniame Baltijos regione, kuri yra tipiška besikeičiančiai embrioninių kopų ir kitų pakrančių buveinių vienmetei augmeni- jai. Lietuvoje ši rūšis yra laikoma išnykusia arba beveik išnykusia, kadangi nebuvo rasta daugiau nei 30 metų, o tik jos hibridai su C. pallasii. Latvijoje didžiausia ir stabiliausia $C$. intermedium populiacija yra rytiniame Rygos įlankos krante. Kitos rūšys, efemerofitai $C$. hyssopifolium ir C. declinatum, taip pat randami sausose pažeistose buveinèse, tačiau pastaraisiais metais jos tapo retesnès. Tuo tarpu potencialiai invazinès $C$. pallasii stebimas didejantis plitimas. Atlikta Estijos ir Latvijos herbariumų rinkinių analizè patvirtino, kad visi C. algidum egzemplioriai buvo identifikuoti kaip C. pallasii arba C. intermedium, o dar dažniau kaip hibridas $C$. intermedium $\times$ C. pallasii. 